\title{
Forensic Accounting: An Ex-Ante - Ex-post Evaluation for India
}

\author{
Sunil V. Mohite \\ Assistant professor, Chhatrapati Shahu Institute of Business Education \\ and Research, Kolhapur, Maharashtra, India
}

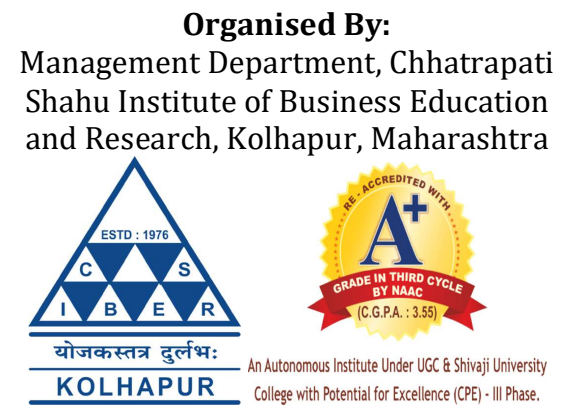

How to cite this paper: Sunil V. Mohite "Forensic Accounting : An Ex-Ante - Expost Evaluation for India" Published in International Journal of Trend in Scientific Research and Development (ijtsrd), ISSN: 2456-6470, Special Issue | Fostering Innovation, Integration and Inclusion Through

Interdisciplinary

Practices in

Management, March

2019, pp.190-195,

URL:

https://www.ijtsrd.c

om/papers/ijtsrd23

099.pdf

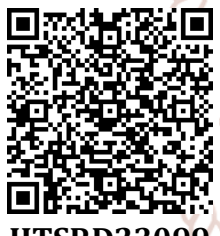

IJTSRD23099
ABSTRACT

Growing incidences of financial fraud have given rise to the field of forensic accounting, a specialty practice area of accounting that focuses on uncovering fraud, among other things. A forensic accounting engagement often involves a detailed assessment of a company's accounting system and processes to determine whether or not the numbers that are presented reflect reality. Unlike financial accounting, forensic accounting is not performed on a routine basis, so it's important for the owner and the executive management team to know when a forensic accountant is needed or should be consulted Incidences of financial fraud have been growing in both frequency and sophistication among businesses in India.

KEYWORDS: Fraud Tracing, Forensic Audit, Evidence, embezzlement, fraudulent, Investigation, Fraud detection

\section{INTRODUCTION}

The practice of forensic accounting was not recognized as a separate practice area distinct from auditing. Over the decades, the auditing function separated itself from fraud detection. As occurred, forensic practice began to develop, and fraud investigation and litigation services began to be offered. As forensic practices followed their own separate path, the services provided changed into those of an investigative nature. Today, with the rash of cybercrimes being committed against every business connected to the Internet, the nature of forensic practice is poised to expand into new territory.
This article reviews the history of forensic accounting, and makes predictions about what the future holds for this practice area. Forensic accounting functions can be limited to financial investigations into a breach in a trusted relationship, or they can be expanded to include any malicious acts against a company's resources. Here, the latter, broader definition will be used. Basic forensic functions include identifying stolen assets, uncovering financial misrepresentations, and locating and tracing money trails. Forensic accountants use aggressive investigative approaches and expect their work to eventually be presented in a legal forum.

\section{History of Forensic Accounting}

The early 1900s, "forensic" accounting first developed to saf eguard businesses expanding in NoNorth America, but there was no specific accounting practice explicitly dealing with fo rensic or fraud issues. The work of the "forensic" accountant was to count company assets and review company accountsf or fraud.There was no auditing attestation function, and ther e were no serious professionalaccounting groups such as the American Institute of CPAs. Today's forensic accounting is ve ry different from thesearch for fraud at the turn of the twenti eth century. The field is still changing today, and it is worthw hile to speculate how much it will change in the future the word was not used at the time-

III. Concept and meaning of Forensic accounting: Forensic accounting can be defined as assistance in disputes regarding allegations or suspicion of fraud, which are likely to involve litigation, expert determination, and enquiry by an appropriate authority and investigations of suspected fraud, irregularity or impropriety which could potentially lead to civil, criminal or disciplinary proceedings. The focus is primarily on accounting issues, but the role of the forensic accountant may extend to more general investigation which includes evidence gathering. It is because of the fact that by definition, forensic assignments are related to judicial or quasi-judicial dispute resolution, that the forensic investigator requires a basic understanding of the applicable statutory and common law, the law of evidence and the law of procedure. The most competently conducted investigation will be of no value to the client should the evidence gathered be ruled to be inadmissible or the expert accounting witness be found to fall short in respect of the requirements of expertise, credibility, or independence 
International Journal of Trend in Scientific Research and Development (IJTSRD) @ www.ijtsrd.com eISSN: 2456-6470

1. "The inclusion of accounting, auditing and investigative expertise are the specialist known as 'Forensic Accounting".

2. 2."Forensic Accounting is the application of accounting principles, theories and discipline to facts or hypotheses at issues in a legal dispute and encompasses every branch of accounting knowledge" according to the American Institute of Certified Public Accountants (AICPA).

3. According to the Journal of Forensic Accounting, "Forensic accounting is sufficiently thorough and complete so that an accountant, in his/her considered independent professional judgment, can deliver a finding as to accounts, inventories, or the presentation thereof that is of such quality that it would be sustainable in some adversarial legal proceeding, or within some judicial or administrative review."

\section{Areas of Forensic Accounting :}

Forensic Accounting may be conducted into the following Areas1 .Fraud and white collar crime investigations. 2. Criminal and civil investigations. 3. Preparation of expert reports. 4. Reviews and evidence. 5. Giving oral evidence in court 6. Insolvency and liquidation support investigation. 7. Fraud prevention and awareness strategies. 8. Fraud and fund tracing. 9.Civil and criminal actions regarding fraud and financial irregularities 10.Breach of contract 11 .Breach of warranty, particularly on company acquisitions 12.Insurance claims Liquidation support 13.Regulatory enquiries 14.Special and confidential investigations 15.Fraud and risk management surveys and reports.

\section{Important Terms and concepts :}

In the lexicon of accounting, terms such as fraud auditing, forensic accounting, fraud examination, fraud investigation, investigative accounting, litigation support, and valuation analysis are not clearly defined.

\section{V.1 Financial Auditors, Fraud Auditors, and Forensic Accountants:}

Some distinctions apply between fraud auditing and forensic accounting. Fraud auditing involves a specialized approach and methodology to discern fraud; that is, the auditor is looking for evidence of fraud. The purpose is to prove or disprove a fraud exists. Historically, forensic accountants, however, have been called in after evidence or suspicion of fraud has surfaced through an allegation, complaint, or discovery.

\section{V.2 Forensic accountants :}

Are experienced, trained, and knowledgeable in all the different processes of fraud investigation including: how to interview people (especially the suspect) effectively, how to write effective reports for clients and courts, how to provide expert testimony in court, and rules of evidence. In recent years, the broadest of these terms in the antifraud profession is forensic accounting, which typically refers to the incorporation of all the terms involved with investigation, including fraud auditing; that is, fraud auditing is a subset of forensic accounting. Fraud investigation usually encompasses about the same thing as a fraud audit except investigation typically involves a lot more nonfinancial evidence, such as testimony from interviews, than a fraud audit. So fraud investigation includes fraud audit but goes beyond it in gathering nonfinancial forensic evidence. Litigation support refers to a forensic accountant assisting attorneys in prosecuting or defending a case in the legal system. That support can take on a variety of skills but ultimately is intended to conclude with the forensic accountant offering an opinion in a court of law as an expert witness on whether a fraud occurred.

\section{V.3 Financial Auditing:}

Is a wholly different term that needs to be distinguished from forensic accounting and fraud auditing. Financial auditing typically refers to the process of evaluating compliance of financial information with regulatory standards, usually for public companies, by an external, independent entity. The well-publicized SOX incorporate concepts and procedures to deter and to catch fraud in audits of internal controls over financial reporting.

However, the focus of financial audits and financial reporting ultimately is concerned with providing reasonable assurance that a material misstatement to financial statements has not occurred, regardless of the reason.

\section{V.4 Financial Auditors:}

The term financial auditor broadly applies to any auditor of financial information or the financial reporting process. The largest classification of financial auditors is those who work for public accounting firms and perform audits of financial statements for public companies. This classification is the most commonly used in this book when referring to financial auditors. Financial auditors have expertise in their knowledge of accounting and financial reporting (such as in generally accepted accounting principles [GAAP], PCAOB standards, or International Financial Reporting Standards [IFRS]), auditing (generally accepted audit standards [GAAS]), and how those standards apply to business transactions. As expressed in the GAAS literature, the most important financial auditing attributes are independence, objectivity, and professional skepticism. Financial auditors traditionally have been seen as, and to an extent have been, numbers oriented, and their processes have been driven by the audit trail. The financial audit procedures are designed to detect material misstatements, and thus financial auditors focus on misstatements that singularly or in the aggregate are large enough to be material. Fraud auditors and forensic accountants are not constrained by materiality. The discipline of financial auditing has been thought to be almost a checklist of items to complete.

In reality, judgment is crucial in financial auditing and has progressively increased in the direction of more dependence on auditor judgment. SOX requirements involve auditor judgment to a large degree; auditors are to understand processes significant to financial reporting and to evaluate management's controls over those processes. Additionally, auditors are to consider environmental, including soft, intangible, factors in that evaluation.

\section{V.5 Fraud Auditors:}

Fraud auditors are generally accountants or auditors, who, by virtue of their attitudes, attribute, skills, knowledge, and experience, are experts at detecting and documenting frauds in books of records of accounting and financial transactions and events. Their particular attitudes include these beliefs: Fraud is possible even in accounting systems that have tight 
controls. The visible part of a transaction fraud may involve a small amount of money, but the invisible portion can be substantial. Red flags of fraud are discernible if one looks long enough and deep enough. Fraud perpetrators can come from any level of management or society.

The skills fraud auditors require include all of those that are required of financial auditors, plus the knowledge of how to gather evidence of and document fraud losses for criminal, civil, contractual, and insurance purposes; how to interview third-party witnesses; and how to testify as an expert witness.

Fraud auditors must know what a fraud is from a legal and audit perspective, an environmental perspective, a perpetrator's perspective, and a cultural perspective. They also need both general and specific kinds of experience. They should have a fair amount of experience in general auditing and fraud auditing, but should have industry-specific experience as well (e.g., banking; insurance; construction; and manufacturing, distribution, and retailing).

Fraud auditing is creating an environment that encourages the detection and prevention of frauds in commercial transactions. In the broadest sense, it is an awareness of many components of fraud, such as the human element, organizational behavior, knowledge of fraud, evidence and standards of proof, an awareness of the potentiality for fraud, and an appreciation of the red flags.

\section{V.5 Differences Among : Forensic accountants, fraud} auditors, and investigative auditors

measure financial transactions in relation to various other authorities, such as the Criminal Code, an insurance contract, institutional policies, or other guidelines for conduct or reporting. Accountant/auditor prepares the report rather than the client or subject and does not include an opinion on the findings. In the investigation, one does not reject evidence as being immaterial; indeed, the smallest item can be the largest clue to the truth. Fraud auditors, forensic accountants, and/or fraud investigators (i.e., all professionals involved with forensic accounting) put things together rather than taking them apart, as is the case in classic financial auditing or the modern method of systems analysis. The process of forensic accounting is also sometimes more intuitive than deductive, although both intuition and deduction play important parts. Financial auditing is more procedural in many regards and is not intended to work as effectively in detecting frauds as the tenets of fraud auditing and forensic accounting.

Fraud means: different things to different people under different circumstances, For instance, fraud can be perceived as deception. One might say that fraud in the form of intentional deception (including lying and cheating) is the opposite of truth, justice, fairness, and equity. Although deception can be intended to coerce people to act against their own self-interest, deception can also be used for one's own defense or survival. Despite that rationale for deception, deception by current standards of behavior is generally considered mean and culpable, but deception can be intended for a benevolent purpose, too.

Fraud as a crime Fraud is a generic term, and embraces all the multifarious means that human ingenuity can devise, which are resorted to by one individual, to get an advantage by false means or representations. No definite and invariable rule can be laid down as a general proposition in defining fraud, as it includes surprise, trick, cunning, and unfair ways by which another is cheated. The only boundaries defining it are those that limit human knavery.

Benevolent deceivers in society are not looked on as harshly as are those whose intentions and motives are impure. Those who act out of greed, jealousy, spite, and revenge are not so quickly excused or forgiven. Fraud can also be associated with injury. One person can injure another either by force or through fraud. The use of force to cause bodily injury is frowned on by most organized societies; using fraud to cause financial injury to another does not always carry the same degree of stigma or punishment. Fraud is a word that has many definitions. Some of the more notable ones are:

\section{Forensic Accounting as Prevention :}

$>$ As regards an appropriate response to fraud which has been detected, every institution requires an integrated corporate strategy. An amoral business environment corrupts honest employees.

$>$ The economy cannot afford business to become a facilitator for crime and dishonesty, merely because it has become convenient not to bring culprits to justice. In developing an appropriate fraud response plan, it is essential that an institution considers the following steps:

$>$ What are the organization's major risk areas and what is its policy stance on perpetrators of fraud? What is the level of fraud awareness within an organization? Are controls effective?

Are customers or trading partners aware of the company's policy on fraud?

$>$ Do employees understand the company's attitude to fraud and dishonesty?

$>$ Can employees report fraud confidentially? Are recruitment practices compatible with an honest workforce? Do disciplinary proceedings dispense justice even-handedly and more importantly, are the seen to do so?

\section{Types of frauds}

$>$ Corporate fraud Corporate fraud is any fraud perpetrated by, for, or against a business corporation.

$>$ Management fraud Management fraud is the intentional misrepresentation of corporate or unit performance levels perpetrated by employees serving in management roles who seek to benefit from such frauds in terms of promotions, bonuses or other economic incentives, and status symbols.

$>$ Layperson's definition of fraud as it is commonly understood today means dishonesty in the form of an intentional deception or a willful misrepresentation of a material fact. Lying, the willful telling of an untruth, and cheating, the gaining of an unfair or unjust advantage over another, could be used to further define the word fraud because these two words denote intention or willingness to deceive

$>$ Specific Frauds and Categories

$>$ As stated earlier, fraud is intentional deception. Its forms are generally referred to as lying and cheating. But theft by guile (larceny by trick, false pretenses, and false tokens) and embezzlement sometimes are included as fraudulent acts. The element of deception is the common ground they all share. But fraud and deception 
International Journal of Trend in Scientific Research and Development (IJTSRD) @ www.ijtsrd.com eISSN: 2456-6470 are abstract terms. They go by many other names aswell. For example, in alphabetical order, they might be called:

Types of fraud in the order of alphabets
\begin{tabular}{|c|l|}
\hline Alphabet & \multicolumn{1}{c|}{ Types of fraud } \\
\hline A & Accounts payable fabrication, Accounts receivable lapping Arson for profit Bank fraud \\
\hline B & $\begin{array}{l}\text { Bankruptcy fraud,Benefit claims fraud ,Bid rigging, Breach of fiduciary duty Breach of trust, Business } \\
\text { opportunity fraud,Bust out . }\end{array}$ \\
\hline C & $\begin{array}{l}\text { Cash lapping heck forgery, Commercial bribery, Computer fraud, Concealment, Consumer fraud } \\
\text {,Conversion, Corporate fraud ,Corruption, Counterfeiting ,Credit card fraud }\end{array}$ \\
\hline D & Defalcation ,Distortion of fact ,Double dealing,Duplicity \\
\hline E & $\begin{array}{l}\text { Electronic funds transfer fraud. Embezzlement .Expense account fraud .False advertising .False and } \\
\text { misleading statement }\end{array}$ \\
\hline F & $\begin{array}{l}\text { False claim False collateral False count False data False identity False information False ownership False } \\
\text { pretenses False report False representation False suggestion False valuation False weights and measures } \\
\text { Fictitious customer Fictitious employees Fictitious person Fictitious vendors, Financial fraud, Financial } \\
\text { misrepresentation Forged documents Forged signatures Forgery Franchising fraud, Fraud in execution } \\
\text { „Fraud in inducement Fraudulent concealment Fraudulent financial statement Fraudulent representation }\end{array}$ \\
\hline I & $\begin{array}{l}\text { Industrial espionage Infringement of copyrights Infringement of patents Infringement of trademarks } \\
\text { Input scam Insider trading Insurance fraud Inventory overstatement Inventory reclassification fraud } \\
\text { Investor fraud }\end{array}$ \\
\hline K & Kickback \\
\hline L & Land fraud Lapping Larceny by trick Loan fraud Lying \\
\hline M & $\begin{array}{l}\text { Mail fraud Management fraud Material misstatement Material omission Misapplication Misappropriation } \\
\text { Misfeasance Misrepresentation }\end{array}$ \\
\hline O & Oil and gas scams Output scams Overbilling Overstatement of revenue \\
\hline
\end{tabular}

\section{Nature of Frauds In India}

Types of Fraud Fraudulent Financial Statements • Employee Fraud • Vendor Fraud • Customer Fraud • Investment Scams - Bankruptcy Frauds • Miscellaneous

VI.1 biggest scams that put India to shame:

Asia-Pacific region. These eight scams show why we have the poor rating. According to International Monetary Fund (IMF), the world wastes up to $\$ 2$ trillion in corruption. That is a significant number: two percent of the world's GDP. With a pressing need to end corruption and foster harmony and stronger ties globally, the United Nations observed International Anti-Corruption Day on December 9. The central theme was 'United against corruption for development, peace and security'.

\section{VI1.1 AbhishekVerma arms deals scandal :}

One man, three scandals: AbhishekVarma is believed to be the main arms dealer and the prime suspect in the Scorpene submarines deal case, Agusta Westland VVIP helicopters bribery scandal, and Navy War Room leak case. He was also named as a suspect in the 2013 Agusta Westland VVIP helicopters bribery scandal, where it was alleged that leaders in Indian government revived bribe exceeding $€ 50$ million.In April 2017, a special CBI court acquitted the couple of the charges.

21Abhishek Verma arms deals scandal :One man, three scandals: AbhishekVarma: Pegged to be possibly the biggest land scam in the country till date, the Karnataka Wakf Board land scam involves the alleged misappropriation of land allocation worth Rs 2,000 billion. Anwar Manippady,

Chairman of the Karnataka State Minorities Commission, said that over 50 percent of the land has been misappropriated by politicians and board members. This was supposedly done in collusion with the real estate mafia for a fraction of its market value under the watch of the Karnataka Wakf Board.

3.1Abhishek Verma arms deals scandal :One man, three scandals: Abhishek Varma Image Credit: Hindustan Times This scam seems to be straight out of a Hollywood movie. In 2002, Abdul Karim Telgi was charged for counterfeiting stamp paper in India. He appointed 350 fake agents to sell stamp papers to banks, insurance companies, and stock brokerage firms. The scam spread across 12 States and the amount involved was pegged at Rs 200 billion.

4. The 'Coalgate' scam :Image Credit: Press Trust of India September 2012 unearthed a scam that involved bureaucrats, political leaders and several ministers from the ruling political party. The Comptroller and Auditor General, India's audit watchdog, reported inefficient and possibly illegal allocation of coal blocks between 2004 and 2009. While initially the loss to the exchequer was pegged at Rs 10.7 lakh crore, the final report stated that the scam amounted to Rs 1.86 lakh crore.

5. 2G Spectrum scam :This scam surfaced when it was revealed that the government, in 2008, had undercharged mobile telephone companies for frequency allocation licences. These licences are used to create $2 \mathrm{G}$ spectrum subscriptions for cell phones.

The Comptroller and Auditor General of India stated that "the difference between the money collected and that mandated to be collected was Rs 1.76 trillion".

6. Adarsh Housing Society scam :A posh 31-storey building located in Colaba, Mumbai, was constructed for the welfare of war widows and personnel of Defence ministry. In 2011, the Comptroller and Auditor General of India observed that over a period 10 years the society flouted various Environment ministry rules. It was noted that politicians, 
bureaucrats and military officers bent several rules concerning land ownership, zoning, and floor-space index.

7. Commonwealth Games scam: The Commonwealth Games scam took India by storm in 2010 involving a pilferage of around Rs 70,000 crore. Since its inception, the games were tangled in a maze of corrupt deals. This included inflated contracts, criminal conspiracy, cheating, and forgery.And in the centre of the corruption was Suresh Kalmadi, the then Pune Loksabha MP.

8. Satyam scam: Dubbed as 'India's Enron scandal', the 2009 corporate scam shook the Indian investors and shareholders community. RamalingaRaju, the Chairman of Satyam Computer Services, confessed that he had falsified the company's accounts, inflating the revenue and profit. The fraud involved Rs 14,000 crore.

\section{Government Initiatives and Anti - Fraud environment in India:}

Anti Fraud Legislations/Regulations/Guidance - Examples Increase in regulators/stakeholders expectation from Management \& Auditors towards Prevention, Detection, Investigation \& Reporting of Fraud ,Indian Contract Act 1872, Indian Penal Code, Prevention of Corruption Act, Prevention of Money Laundering Act, The Companies Act 1956 , Clause 49 of Listing Agreement, CARO 2003 of 10 people in India, the study stated, had to pay a bribe to access public services.

Even measures to tackle corruption and curb the growing menace of black money has dominated the national discourse over the past years. Various policies and legislations, including the implementation of Goods and Services Tax and the demonetization of high-value currencies were some of the steps taken by the Central government in a bid to make India corruption-free. As the world recently observed International Anti-Corruption Day, and countries across the world reaffirmed their resolve to end corruption, let's take a look at some of the biggest scams that startled India.

\section{Conclusion}

Growing incidences of financial fraud have given rise to the field of forensic accounting, a specialty practice area of accounting that focuses on uncovering fraud, among other things. A forensic accounting engagement often involves a detailed assessment of a company's accounting system and processes to determine whether or not the numbers that are presented reflect reality. Unlike financial accounting, forensic accounting is not performed on a routine basis, so it's important for the owner and the executive management team to know when a forensic accountant is needed or should be consulted incidences of financial fraud have been growing in both frequency and sophistication among $\mathrm{m}$ businesses in India, especially as the economic recovery drags on and some employees give in to the temptation to embezzle funds from their employers. This is one factor that has given rise to the field of forensic accounting. But it's often not clear what the difference is between forensic accounting and financial accounting. Forensic accounting is a specialty practice area of accounting that focuses on uncovering financial fraud. It also encompasses other types of engagements resulting from disputes and litigation between parties. In fact, the term "forensic" means "suitable for use in a court of law."

A forensic accounting engagement often involves a detailed assessment of a company's accounting system and processes to determine whether or not the numbers that are presented do, in fact, reflect reality. Following is a more detailed look at the main differences between forensic accounting and financial accounting.

\section{Reference}

\section{Articles}

[1] The Role of Auditors in Preventing, Detecting, and Reporting Fraud: The Case of the United Arab Emirates (UAE).\| By Dr. Sawsan Saadi Halbouni, International Journal of Auditing, Vol. 19, Issue 2, pp. 117-130, 2015

[2] Asia's Enron: Satyam (Sanskrit Word for Truth)\| by Elisabetta Basilico, Hugh Grove, Lorenzo Patelli, Journal of Forensic \& Investigative Accounting, Vol. 4, Issue 2, 2012

[3] Crumbley, D. Larry; Heitger, Lester E.; Smith, G. Stevenson (2005-08-05). Forensic and Investigative Accounting. CCH Group. ISBN 0-8080-1365-3.

[4] Cicchella, Denise (2005). Construction audit guide: overview, monitoring, and auditing. Altamonte Springs, FL: IIA Research Foundation. ISBN 0-89413-587-2.

[5] Parr, Russell L.; Smith, Gordon V. (2010). Intellectual property: valuation, exploitation, and infringement damages. Hoboken, N. J.: Wiley. pp. Chapter 33. ISBN 0470-45703-1.

[6] W. S. Hopwood, J. J. Leiner\& G. R. Young, Forensic Accounting, McGraw-Hill Irwin (2008), as quoted by Stephen Pedneault, Frank Rudewicz, Michael Sheetz\& Howard Silverstone, Forensic Accounting and Fraud Investigation, John Wiley \& Sons, Inc. (4th ed. 2017).

[7] Nigrini, Mark (June 2011). "Forensic Analytics: Methods and Techniques for Forensic Accounting Investigations". Hoboken, NJ: John Wiley \& Sons Inc. ISBN 978-0-470-89046-2.

[8] "Forensic Auditor Courses catching up in India". business- standard.com. Retrieved 2014-05-18.

[9] "Service of Forensic Accountants".big4accountingfirms.org. Retrieved 201404-08.

[10] Bologna J., Lindquist J. Robert, Fraud Auditing and Forensic Accounting: New Tools and Technique, John Willey \& Sons, Hobokon, New Jersey, Canada, 2004

[11] Cascirino, A., Richards, Auditor's Guide to IT Auditing, John Willey and Sons, Hoboken, New Jersey, 2012

[12] Nigrini J. Mark, Benford's Law: Application of Forensic Accounting, Auditing, and Fraud Detection,

[13] John W-Corporate Accounting Fraud: A Case Study of Satyam Computers Limited\| by Madan Lal Bhasin, Bang College of Business, KIMEP University, Almaty, Republic of Kazakhstan, Open Journal of Accounting, 2013, 2, 26-38

[14] Roundtable on The Role of Forensic and Investigative Accounting: Challenges for the Banking Industryll 
International Journal of Trend in Scientific Research and Development (IJTSRD) @ www.ijtsrd.com eISSN: 2456-6470

Nigerian Institute of Advanced Legal Studies Lagos, Nigeria, 19th July, 2010

[15] Forensic Accounting: A New Paradigm For Niche Consulting\| by Dr. MadanBhasin, The Chartered Accountant January 2007

[16] Forensic Accounting - Investigative Auditing using CAATTs by Nikunj S. Shahilley\& Sons, Hobokon, New Jersey, Canada, 2012

[17] Forensic Auditing\| by S. Vasudevan, The Chartered Accountant, September 2004

[18] Forensic Accountant: Recognition in Indian Law\| by Neeraj Arora

Websites and internet

[1] https://books.google.com/

[2] www.businessdictionary.com/definition/researchmeth odology.html

[3] https://en.wikipedia.org/wiki/Methodology
[4] stattrek.com/statistics/measurement-scales.aspx? Tutorial $=\mathrm{AP}$

[5] dissertation.laerd.com/reliability-in-research.php

[6] https://www.uni.edu/chfasoa/reliabilityandvalidity.ht $\mathrm{m}$

[7] www.socialresearchmethods.net > Home > Measurement

[8] www.nova.edu/ssss/QR/QR8-4/golafshani.pdf

[9] allpsych.com > Research Methods

[10] www.forensicaccounting.com

Copyright (C) 2019 by author(s) and International Journal of Trend in Scientific Research and Development

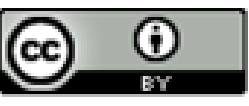
Journal. This is an Open Access article distributed under the terms of the Creative Commons Attribution License (CC BY 4.0) (http://creativecommons.org/licenses/by/4.0) 